\title{
An approach to the study of the fungal deterioration of a classical art material: Mastic varnish
}

\author{
Julio Romero-Noguera ${ }^{1} \square \cdot$ María del Mar López-Miras $^{2} \cdot$ Inés Martín-Sánchez $^{2}$. \\ José Miguel Ramos-López ${ }^{3}$. Fernando Bolívar-Galiano ${ }^{1}$ \\ 1 Faculty of Arts, University of Granada, Granada, Spain \\ 2 Faculty of Sciences, University of Granada, Granada, Spain \\ 3 Scientific Instrumentation Center, University of Granada, Granada, Spain
}

$\triangle$ Corresponding author: juliorn@ugr.es

Received June 24, 2010 / Accepted October 6, 2010

Published online: November 15, 2010

(C) 2010 by Pontificia Universidad Católica de Valparaíso, Chile

\begin{abstract}
Mastic, one of the best natural varnishes, is frequently used as protective and finishing layer or as component of oleo-resinous media in paintings, both in the past and currently. However, this resin is affected by complex deterioration processes which can change its characteristics and thus the visual aspect of works of art. The alteration processes caused by radiation have been widely studied, but there is a lack of information on the biodeterioration of this natural product. In this paper, fungi from collections as well as from oil paintings of the Fine Arts Museum of Granada (Spain) were inoculated onto slides covered with mastic. The samples, after an incubation period of 15 days, were analysed by gas chromatography-mass spectrometry (GC-MS) to identify the chemical changes undergone, and a visual monitoring of the samples was performed to determine the formation of mycelia onto solidified resins. Major changes were detected in Chrysonilia sitophila, Phoma herbarum, and P. chrysogenum, showing evidence of alteration processes caused or favoured by these microorgamisms.
\end{abstract}

Keywords: biodeterioration, fungi, GC-MS, mastic

\section{INTRODUCTION}

Triterpenoid resins (mastic and dammar) yield the natural varnishes most widely used in painting and polychrome sculpture, because they are less prone to yellowing compared to other natural resins and because of their excellent optical properties, superior to those of more stable synthetic varnishes. Mastic is the resin of the mastic tree (Pistacia lentiscus, from the Anacardiaceae family). The major source of mastic is the sub-specie Pistacia lentiscus L. var. Chia from the Greek island Chios. Because of its Mediterranean origin, mastic has been employed since the Bronze Age for varied uses, as the manufacture of ceramics or the preparation of Egyptian mummies. The first artistic recipes were mixes generally used as final protective coating, prepared with turpentine or ethanol, in which frequently entered other components such as linseed oil, sandarac or colophony. During the 18th and 19th centuries, mastic was utilized as a component of binding media mixed with linseed oil (melgip), subsequently abandoned because of its scant stability. After the appearance of dammar resin in Occident (around 1830), considered the best natural resin for its hardness and smaller tendency to efflorescence and yellowing, the use of mastic decreased. However, many artists continue nowadays employing this resin as final protective layer or as a component of binding media for painting (Mayer, 1991; Masschelein-Kleiner, 1992; Mills and White, 1999).

Mastic resin consists of complex mixtures of substances formed from squalene that present a $30-\mathrm{C}$ structure. The predominating acids are pentacycles of the oleanane series, such as amyrone derivatives, and oleanonic and moronic acids (Figure 1). The latter is a highly stable compound, used as a mastic analytical marker in ancient works of art. Other important components are tetracycles of the euphane (e.g. masticadienoic acid) and dammarane type, such as hydroxydammarenone (Masschelein-Kleiner, 1992; Mills and White, 1999; Assimopoulou and Papageorgiou, 2005a; 
Assimopoulou and Papageorgiou, 2005b). To a lesser extent, bicyclic and tricyclic triterpenoids have been described, as well as an apolar polymer ( $2 \%$ of the whole resin) composed of cis- $1,4-$ poly- $\beta$ myrcene (Van den Berg et al. 1998).

The aim of the present paper is to study the capacity of growth on mastic varnish of fungi frequently mentioned in works on biodeterioration of paintings and sculptures, as well as the processes of chemical alteration that these organisms can cause. There is a lack of literature on biodeterioration of mastic resin used in works of art, despite the importance of these processes when the conservation conditions are inadequate. Long exposures to high levels of relative humidity promote the growth of microorganisms, which can lead to opacifications, changes of tonality, deterioration of the support and even the loss of pictorial strata, substantially altering the visual aspect and the integrity of the work of art.

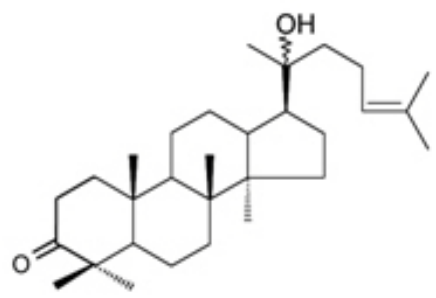

hydroxydammarenone

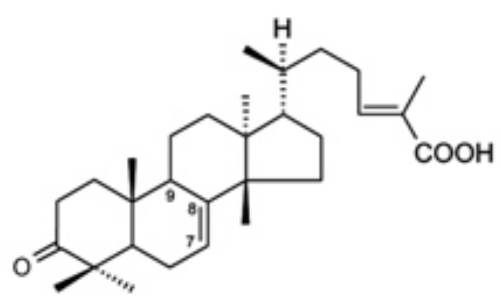

masticadienoic acid

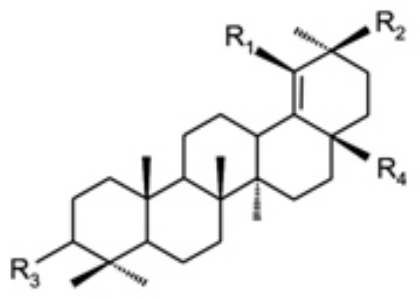

$\begin{array}{lcccc} & \underline{\mathrm{R}_{1}} & \underline{\mathrm{R}_{2}} & \underline{\mathrm{R}_{3}} & \underline{\mathrm{R}_{4}} \\ \text { amyrone } & \mathrm{H} / \mathrm{CH}_{3} & \mathrm{H} / \mathrm{CH}_{3} & \mathrm{O} & \mathrm{CH}_{3} \\ \text { nor-amyrone } & \mathrm{H} / \mathrm{CH}_{3} & \mathrm{H}^{-\mathrm{CH}_{3}} & \mathrm{O} & \mathrm{H} \\ \text { oleanonic aldehyde } & \mathrm{H} & \mathrm{CH}_{3} & \mathrm{O} & \mathrm{CHO} \\ \text { oleanolic acid } & \mathrm{H} & \mathrm{CH}_{3} & \mathrm{OH}, \mathrm{H} & \mathrm{COOH} \\ \text { oleanonic acid }^{1} & \mathrm{H} & \mathrm{CH}_{3} & \mathrm{O} & \mathrm{COOH} \\ \text { moronic acid }^{1} & \mathrm{H} & \mathrm{CH}_{3} & \mathrm{O} & \mathrm{COOH}\end{array}$

1

In moronic acid the double bond is located at $\mathrm{C} 18$

Fig. 1 Scheme showing the main triterpenoid compounds described in mastic.

Our research team (Domenech-Carbó et al. 2006) published an initial study on the biodeterioration of mastic resin which, as will be commented in the discussion section, offers the only available information to date. This study was performed only with microorganisms from collections, and by inoculating fungal mycelia on the resins, instead of suspensions of spores, as in the present case. On the other hand, the resin studied presented a quite different composition with respect to the mastic analysed here. Thus, we consider the present paper be new and independent research.

By contrast, analytic studies have been published on naturally aged varnishes from paintings (Van der Doelen et al. 1998b; Colombini et al. 2000) and on resins exposed to accelerated photoageing processes (Van der Doelen et al. 1998a; Van der Doelen and Boon, 2000). The main alterations 
involving these materials are the yellowing and the increasing fragility which results in microcrack and macrocrack patterns, as well as augmented polarity and changes in solubility (Doménech-Carbó et al. 2006; Romero-Noguera et al. 2008). These processes are closely linked to oxidation, which can vary depending on the chemical structure of the components. Tetracycles of the oleanane/ursane type oxidize mainly on C-28. Other major processes described are C-28 decarboxylation, C-17 hydroxylation, and $\mathrm{C}-11$ oxidation to ketone. The main processes of oxidation in dammaranes affect the double bonds of the side chain, leading to hydroxyl groups that develop into epoxidic or lactonic structures in aged resins. In strongly aged varnishes cleavage reactions can occur, leading to the formation of low molecular weight products, with loss of the oleanane/ursane skeleton, and the subsequent drop in the whole amount of free triterpenoids. Under such conditions, moronic acid has been found to be the most stable compound, so that it is used as an analytical marker for the presence of mastic in works of art (Van der Doelen et al. 1998a; Van der Doelen and Boon, 2000).

On the other hand, quantitative studies performed by gas chromatography-mass spectrometry (GCMS) show that the total quantity of triterpenoids decreases over time, whereas the fraction of crosslinked high molecular weight products increases. The cross-linked fraction has been related to yellowing phenomena, since oxidized free triterpenes do not absorb in ultraviolet-visible spectrophotometry (UV-VIS) (Van der Doelen and Boon, 2000). The chemical study of these ageing processes proves quite difficult because of the complex composition of varnishes, their variability, and the frequent presence of others substances used in artistic techniques.

\section{MATERIALS AND METHODS}

\section{Varnish}

The studied varnish was prepared with mastic resin of Chios, supplied by Caremi Pigmentos (Sevilla, España). This was dissolved in purified turpentine essence, supplied by Titan (Barcelona, España), in the proportion of $175 \mathrm{~g}$ of resin per $300 \mathrm{ml}$ of turpentine essence (Mayer, 1991).

\section{Microorganisms}

The microorganisms used in the experiments are commonly mentioned in papers on biodeterioration of works of art. Some of them have shown its capability to deteriorate other terpenoid varnishes in earlier works of our research team (Doménech-Carbó et al. 2006; Romero-Noguera et al. 2008; RomeroNoguera et al. 2010).

The microorganisms studied were: Aspergillus niger (An) (CECT-2088, ATCC 9029); Aureobasidium pullulans (Au) (CECT-2703, ATCC 9348); Cladosporium cladosporioides (Cc) (CECT 2110, ATCC

Table 1. List of compounds corresponding to the marked peaks in Figure 4 (Mw: molecular weight; ID: Identification; L: Wiley Mass Spectra Library; R: References).

\begin{tabular}{cccc}
\hline $\mathbf{N}^{\mathbf{0}}$ & Compound & $\mathbf{M w}$ & $\mathrm{ID}$ \\
1 & nor- $\beta$-amyrone & 410 & $\mathrm{R}$ \\
2 & $\beta$-amyrone & 424 & $\mathrm{R}$ \\
\hline 3 & nor-a-amyrone & 410 & $\mathrm{R}$ \\
\hline 4 & $\alpha$-amyrone & 424 & $\mathrm{R}$ \\
\hline 5 & moronic acid, methyl ester & 468 & $\mathrm{~L}$ \\
\hline 6 & oleanonic acid, methyl ester & 468 & $\mathrm{~L}$ \\
\hline 7 & Hydroxydammarenone & 442 & $\mathrm{R}$ \\
\hline 8 & oleanonic aldehyde & 438 & $\mathrm{R}$ \\
\hline 9 & masticadienoic acid (or isomer), methyl ester & 468 & $\mathrm{R}$ \\
\hline 10 & masticadienoic acid (or isomer), methyl ester & 468 & $\mathrm{R}$ \\
\hline
\end{tabular}


16022); Penicillium chrysogenum (Pc) (CECT-2306, ATCC 8537); Rhizopus oryzae (Ro) (CECT-2339, ATCC 11145); Mucor rouxii (Mr) (CECT-2655, ATCC 24905) and Trichoderma pseudokoningii (Tp) (CECT-2937). They all came from stock collections belonging to the Spanish Collection of Type Cultures (CECT, Colección Española de Cultivos Tipo, University of Valencia, Valencia, Spain).

The study also included the fungi Aspergillus versicolor, Phoma herbarum, Chrysonilia sitophila, and Cladosporium sp. They were isolated from the surface of paintings of the Fine Arts Museum of Granada (Spain) entitled "Allegory of Death" (by P. Toma, $17^{\text {th }}$ century, oil on canvas) and "St. Francis of Assisi" (Anonymous, $17^{\text {th }}$ century, oil on canvas), severely affected by biodeterioration processes.

\section{Test specimens preparation}

Glass slides of standard size $(24 \times 80 \mathrm{~mm})$, covered with mastic were used as test specimens. The varnish was applied by brush in three successive layers (about $0.5 \mathrm{~mm}$ thickness). The specimens were dried in darkness at $20^{\circ} \mathrm{C}$ and $55 \% \mathrm{RH}$ for 90 days.

To obtain fungal spores, lyophilized collection stocks were hydrated in malt extract broth (Oxoid) and incubated for one week. Afterwards, cultures were spread on malt extract agar (Oxoid) medium and incubated for 15 days. Sporulated cultures were resuspended in $2 \mathrm{ml}$ of Tween $800.1 \%$ (Aldrich). After centrifugation, pellets were washed and resuspended in $2 \mathrm{ml}$ of distilled water. The suspensions were filtered through glass wool to eliminate any remains of mycelium. After a count in a Neubauer chamber, the concentration was adjusted to $10^{6}$ spore $\mathrm{ml}^{-1}$, and several drops $(75 \mu \mathrm{l})$ of these suspensions (one fungus per test specimen, not mixes) were inoculated on supports.

Previous experiments (Romero-Noguera et al. 2008) helped us to establish the optimal conditions for incubating the test specimens. These were incubated for 15 days in darkness at $28^{\circ} \mathrm{C}$ and $85-90 \% \mathrm{RH}$, water activity $\left(a_{w}\right)=0.85$.
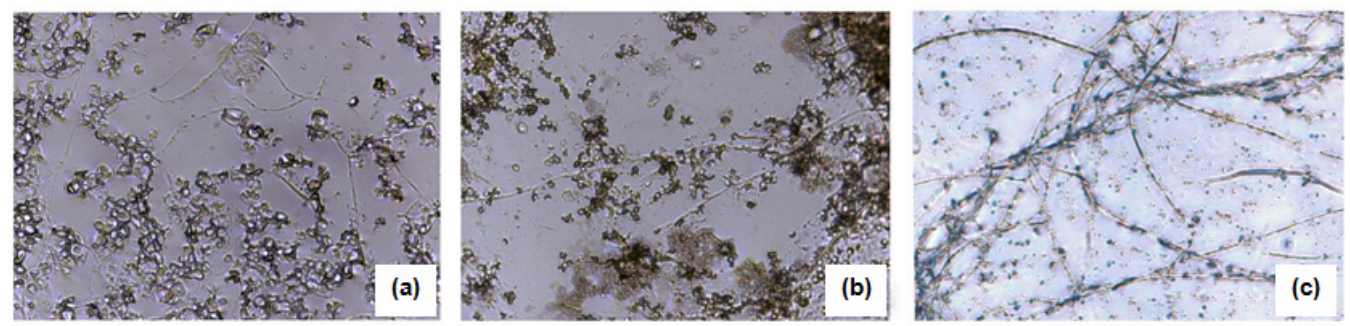

Fig. 2 Microphotographs (400x) showing fungal growth after 15 days of incubation. (a) C. sitophila. (b) $P$. chrysogenum. (c) P. herbarum.

\section{Instrumentation and procedures}

A sterile scalpel was used to scrape the samples from the test specimens, providing about $0.5 \mathrm{mg}$ per sample. These were dissolved in $25 \mu \mathrm{l}$ of benzene. Then, $25 \mu \mathrm{l}$ of (m-trifluoro-methylphenyl) trimethylammonium hydroxide (Meth Prep II, Alltech) were added. The reaction mixture was shaken for about $40 \mathrm{~min}$ at room temperature. $1 \mu \mathrm{l}$ of the sample solution was injected into the GC. Analyses were carried out using a Platform II mass spectrometer (Micromass Instruments, UK) coupled to a Carlo Erba 8060 gas chromatograph (Thermo Instruments, USA). Chromatographic separations were achieved on a fused-silica capillary column (HP-1MS), (100\% dimethylpolysiloxane), $30 \mathrm{~m} \times 0.25 \mathrm{~mm}$ i.d. and $0.25 \mu \mathrm{m}$ film thickness. The chromatographic conditions for the GC-MS analysis were: injector temperature $=250^{\circ} \mathrm{C}$; transfer line temperature $=300^{\circ} \mathrm{C}$; oven temperature $=120^{\circ} \mathrm{C}(2 \mathrm{~min}) ; 10^{\circ} \mathrm{C} / \mathrm{min}$ to $300^{\circ} \mathrm{C}$ then isothermal for $20 \mathrm{~min}$. The carrier gas was helium at a flow-rate of $1.2 \mathrm{ml} / \mathrm{min}$. Samples were injected in splitless mode. Mass spectra were performed in total ion monitoring mode (mass range $50-550 \mathrm{~m} / \mathrm{z}$ ) and ions were generated by electron impact ionisation $(70 \mathrm{eV})$. The source temperature was $210^{\circ} \mathrm{C}$. A MassLynx v.4.0 data system was used for data acquisition and processing and the peak area (total ion chromatography, TIC) data were used to obtain peak area percentage value. 
Calculations were based on values of the normalized peak area $N_{i}$, defined as the percentage of peak area of each individual compound relative to the set of peak areas of the $n$ components found in the sample:

$$
\mathrm{N}_{\mathrm{i}}=\frac{A_{i}}{\sum_{i=1}^{n} A_{i}} \times 100
$$

where $A i$ is the peak area of each of the $n$ compounds found in the chromatogram.

Blank samples, inoculated with distilled water and incubated under the same conditions as those of the samples inoculated with microorganisms, were also analysed. The changes in the composition respect to the samples inoculated with microorganisms were determined by establishing a $\Delta N_{i}$ parameter, defined as the increase or decrease in $N_{i}$ for each analyte in relation to the values corresponding to the blank sample $N_{i o}$.

$$
\Delta N_{i}=N_{i}-N_{i 0}
$$

A total of three replicates for each sample were used. The values considered for results were the average of the triplicate groups. The repeatability found under the experimental conditions and the relative standard deviations - calculated using the formula RSD $=$ (standard deviation $/$ mean of the normalized peak area) $\times 100 \%$-fell within the range $1-5 \%$ for all the compounds analysed. The Student's t-test was used for comparison of the differences between means values of inoculated and non inoculated (blank) samples. Only the values with a $P<0.05$ were considered statistically significant.

\section{RESULTS AND DISCUSSION}

\section{Control of fungal growth}

The evolution of test specimens inoculated with fungi was monitored by means of surveillance photography of colonial morphology at 0,24 , and $48 \mathrm{hrs}$, and at 5,10 , and 15 days using a Nikon Eclipse TS100 microscope equipped with a Nikon DS-5M digital camera. Three fungi, C. sitophila, $P$. chrysogenum, and $P$. herbarum were found to grow on test specimens (Figure 2). The main significant

Table 2. GC-MS analysis ( $P<0.05$ in all cases) of triterpenoids of blank sample (in bolds), and samples

\begin{tabular}{|c|c|c|c|c|}
\hline Compound & Mastic & C. sitophila & P. chrysogenum & P. herbarum \\
\hline nor-a-amyrone & 5.99 & -2.94 & -5.12 & -5.12 \\
\hline a-amyrone & 1.69 & -0.88 & -1.23 & -1.47 \\
\hline nor- $\beta$-amyrone & 30.12 & -4.97 & -14.50 & -13.54 \\
\hline$\beta$-amyrone & 2.36 & +1.74 & -0.11 & -0.16 \\
\hline moronic acid & 10.03 & +10.17 & +15.01 & +19.36 \\
\hline $\begin{array}{l}\text { oleanonic acid } \\
\text { OH-dammarenone }\end{array}$ & 36.90 & -5.94 & -7.53 & -9.45 \\
\hline oleanonic aldehyde & 5.54 & +0.76 & +1.32 & -0.60 \\
\hline $\begin{array}{l}\text { masticadienoic acid } \\
\text { (or isomer) }\end{array}$ & 0.40 & +2.05 & +2.04 & +2.87 \\
\hline $\begin{array}{l}\text { masticadienoic acid } \\
\text { (or isomer) }\end{array}$ & 2.90 & +1.03 & +10.46 & +7.71 \\
\hline
\end{tabular}
inoculated with microorganisms (average values expressed respectively in $N_{i}$ and $\Delta N_{i}$ ). 
changes were always detected in the first $48 \mathrm{hrs}$ of incubation, and in no case were significant changes detected after 5 days of incubation. Serious visual damages were detected in these samples, consisting of microcracks (opacifications) and macrocrack patterns (visible fissures), appreciable in these three microorganisms, and tonality changes (a slight yellowing, especially in the case of $P$. herbarum).

\section{Gas chromatography/ mass spectrometry}

The Figure 3 shows the region of triterpenoids of the TIC of mastic after derivatization with Meth-Prep II. The labels for the peaks are explained in Table 1. The compounds were identified according to the database (Table 1, L) of the Wiley Mass Spectra Library, and the mass spectra published (Table 1, R) in the literature (Van der Doelen et al. 1998a; Van der Doelen et al. 1998b; Van der Doelen and Boon, 2000; Assimopoulou and Papageorgiou, 2005a; Assimopoulou and Papageorgiou, 2005b).

The analytical results are shown in Table $2(P<0.05$ in all cases). The blank sample consisted of nora-amyrone $\left(N_{i}=30.12 \%\right)$, moronic acid $\left(N_{i}=10.03 \%\right)$, oleanonic acid-hydroxydammarenone $(36.80 \%)$, and smaller amounts of nor- $\beta$-amyrone $\left(N_{i}=5.99 \%\right)$, oleanonic aldehyde $\left(N_{i}=5.54 \%\right)$, as well as $\alpha$ amyrone, $\beta$ amyrone, and masticadienoic acid. Similar results were found in the case of additional control samples inoculated with inactivated spores (A. niger).

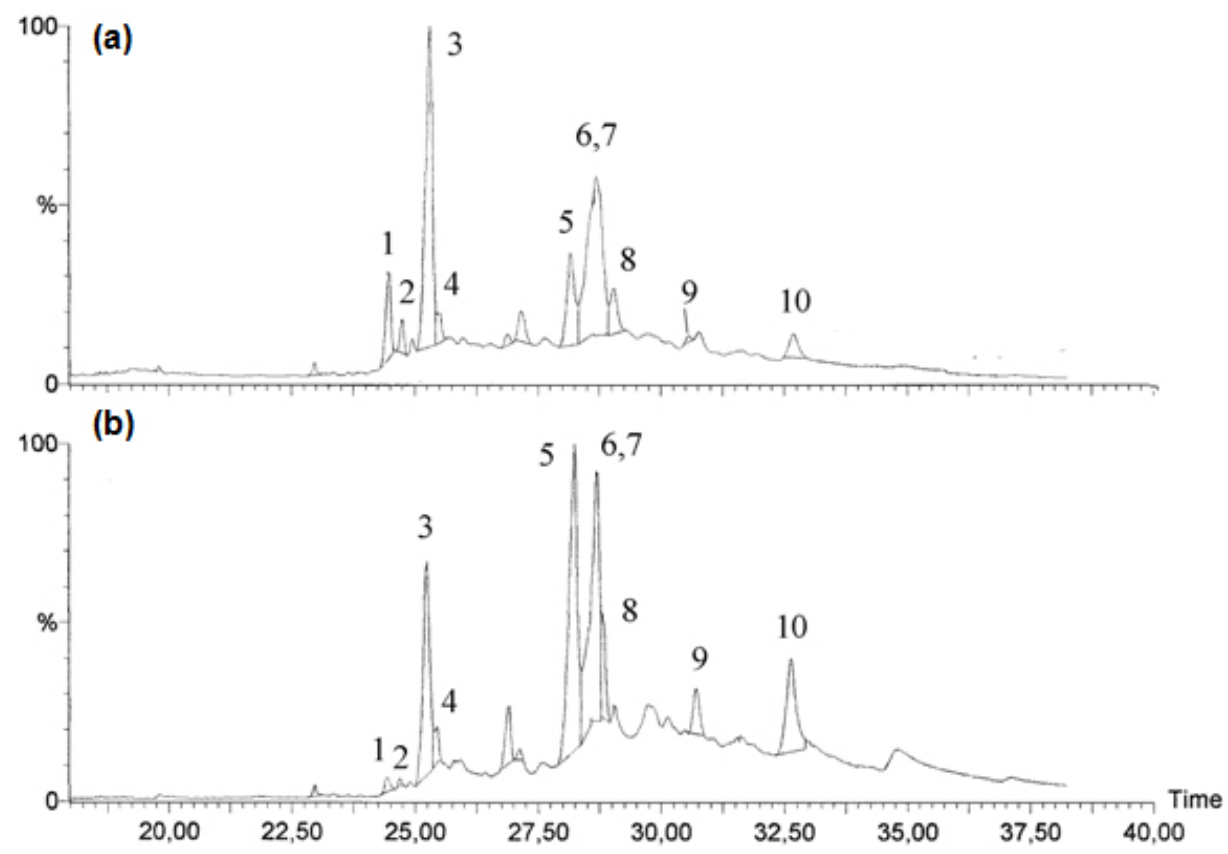

Fig. 3 Chromatograms corresponding with $\boldsymbol{P}$. herbarum. Labels are explained in Table 1. (a) Mastic varnish control. (b) Mastic varnish inoculated.

In the samples in which fungal growth was detected, the most significant findings (Table 2, Figure 4) were a strong increase in the relative amount of the compound considered the most stable, moronic acid, with $\Delta N_{i}$ values ranging from +10.17 (C. sitophila) to +19.36 ( $P$. herbarum). This matches with a general fall of the peak in the co-elution of oleanonic acid and hydroxydammarenone, which fell within the range $\Delta N_{i}=-9.45$ ( $P$. herbarum) to $\Delta N_{i}=-5.94$ (C. sitophila). Another important difference with respect to standard varnish was observed in the relative amounts of nor- $\alpha$-amyrone and nor- $\beta$ amyrone, which sharply decreased in $P$. herbarum and $P$. chrysogenum. Regarding the minority tetracyclic fraction, basically integrated by masticadienoic acid and its isomer, the stability of one of these compounds (retention time, $\mathrm{tR}=32 \mathrm{~min}$ ) is remarkable (Table 2), the values of $\Delta N_{i}$ reaching +7.71 ( $P$. herbarum) and +10.46 ( $P$. chrysogenum). 
The present results resemble with those found in works dedicated to natural or artificial ageing (by UV radiation) of mastic varnish (Van der Doelen et al. 1998a; Van der Doelen et al. 1998b; Colombini et al. 2000; Van der Doelen and Boon, 2000), where an increase in the most stable compounds (e.g. moronic acid) accompanied by a degradation of the rest, was associated with such processes as yellowing, opacification, and microcrack as well as and macrocrack patterns.

In terms of biodeterioration, Doménech-Carbó et al. (2006) studied the changes in mastic varnish inoculated with mycelia (non only spores, as in this case) of Aspergillus niger, Cladosporium cladosporoides, Penicillium chrysogenum, and Trichoderma pseudokoningii, all from collection stocks. The analysis was performed by GC-MS before derivatization with methyl chloroformate, and the standard mastic sample (purchased from Agar-Agar, Vigo, Spain) presented a quite different composition, based on hexakisnor-dammaran-3-20-dione, nor-olean-17-en-3-one, hydroxydammarenone, and moronic and masticadienoic acids, as well as a small fraction of more oxidized degradation products. The $\Delta N_{i}$ values found were rather scattered, but $P$. chrysogenum showed a pattern similar to that observed here: a decrease in amyrone derivatives and an increase in moronic acid as well as the ocotillone-type compound 20.24-epoxy-25-hydroxy-dammaran-3-one.

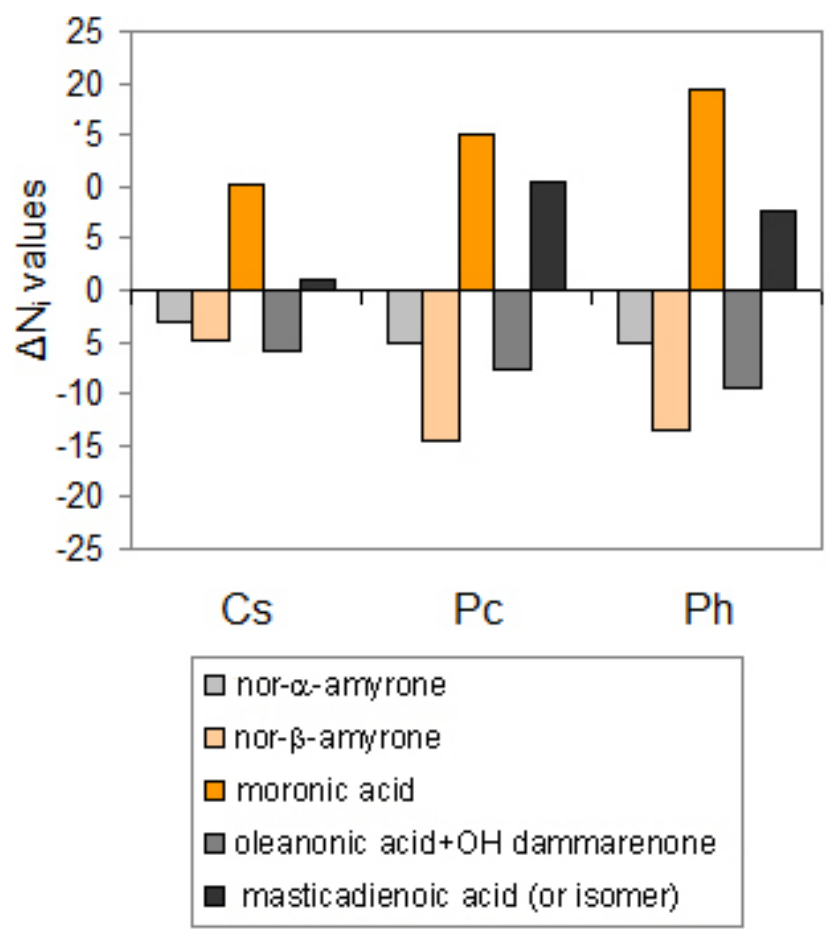

Fig. $4 \mathrm{GC}-\mathrm{MS}$ analysis $\left(\Delta N_{i}\right.$ values) of mastic samples inoculated with microorganisms, Cs: C. sitophila; Pc: P. chrysogenum; Ph: P. herbarum.

No specific degradation pathways were found to occur. Presumably, the observed changes were due to the formation of polymerized and/or low molecular weight products, both nondetectable by GC-MS. In no case were strongly oxidized compounds and pronounced alterations as those described in Van der Doelen and Boon (2000) detected. This was to be expected, as these studies were made under very aggressive treatments (artificial ageing, long UV exposure, liquid medium, very old resins) with respect to those chosen for the present study. However, the observed changes led to the expectation of further greater transformations in real cases of bad conservation conditions, (especially long exposure to high relative humidity combined with continuous contribution of microorganisms and organic material from the environment). 


\section{CONCLUDING REMARKS}

Three of the fungi studied (C. sitophila, $P$. chrysogenum and $P$. herbarum) formed mycelium onto the mastic varnish after incubation for 15 days $\left(28^{\circ} \mathrm{C}\right.$ and $\left.85-90 \% \mathrm{RH}\right)$. The most important chemical changes detected (GC-MS) in these samples were the maintenance of the compounds considered most stable, i.e. moronic and masticadienoic acid, accompanied by a degradation of the rest. Also, serious visual damages were detected, consisting of microcracks (opacifications), macrocrack patterns, and tonality changes (yellowing). The present results are consistent with those found in works dedicated to natural or artificial ageing of filmogenic triterpenoid materials, suggesting that these microorganisms cause or promote deterioration processes of mastic varnish.

Financial support: This study was supported by the National Spanish Project "I+D+I MCYT" CTQ2005-09339-C0303.

\section{REFERENCES}

ASSIMOPOULOU, A.N. and PAPAGEORGIOU, V.P. (2005a). GC-MS analysis of penta- and tetra-cyclic triterpenes from resins of Pistacia species. Part I: Pistacia lentiscus var. Chia. Biomedical Chromatography, vol. 19, no. 4, p. 285-311. [CrossRef]

ASSIMOPOULOU, A.N. and PAPAGEORGIOU, V.P. (2005b). GC-MS analysis of penta- and tetra-cyclic triterpenes from resins of Pistacia species. Part II: Pistacia terebinthus var. Chia. Biomedical Chromatography, vol. 19, vol. 8, p. 586-605. [CrossRef]

COLOMBINI, M.P.; MODUGNO, F.; GIANNARELLI, S.; FUOCO, R. and MATTEINI, M. (2000). GC-MS characterization of paint varnishes. Microchemical Journal, vol. 67, no. 1-3, p. 385-396. [CrossRef]

DOMÉNECH-CARBÓ, M.T.; OSETE-CORTINA, L.; DE LA CRUZ-CAÑIZARES, J.; BOLÍVAR-GALIANO, F.; ROMERO-NOGUERA, J.; FERNÁNDEZ-VIVAS, M.A. and MARTÍN-SÁNCHEZ, I. (2006). Study of the microbiodegradation of terpenoid resin-based varnishes from easel painting using pyrolysis-gas chromatography-mass spectrometry and gas chromatography-mass spectrometry. Analytical and Bioanalytical Chemistry, vol. 385, no. 7, p. 1265-1280. [CrossRef]

MASSCHELEIN-KLEINER, L. (1992). Liants, vernis et adhésifs anciens. Bruxelles, Institut Royal du Patrimoine Artistique. 123 p. ISBN 2-930054-01-8.

MAYER, R. (1991). The artist's handbook of materials and techniques. $5^{\text {th }}$ ed. New York, Penguin Books. $761 \mathrm{p}$. ISBN 0-670-83701-6.

MILLS, J.S. and WHITE, R. (1999). The organic chemistry of museum objects. $2^{\text {nd }}$ ed. Oxford, ButterworthsHeinemann. 206 p. ISBN 0750646934

ROMERO-NOGUERA, J.; BOLIVAR-GALIANO, F.C.; RAMOS-LÓPEZ, J.M.; FERNÁNDEZ VIVAS, M.A. and MARTÍN-SÁNCHEZ, I. (2008). Study of biodeterioration of diterpenic varnishes used in art painting: Colophony and Venetian turpentine. International Biodeterioration \& Biodegradation, vol. 62, no. 4, p. 427433. [CrossRef]

ROMERO-NOGUERA, J.; MARTÍN-SÁNCHEZ, I.; RAMOS-LÓPEZ, J.M. and BOLÍVAR-GALIANO, F. (2010). Biodeterioration patterns found in dammar resin used as art material. Electronic Journal of Biotechnology, vol 13, no. 3. [CrossRef]

VAN DEN BERG, K.J.; VAN DER HORST, J.; BOON, J.J. and SUDEIIJER, O.O. (1998). Cis-1,4-poly- $\beta$-myrcene; the structure of the polymeric fraction of mastic resin (Pistacia lentiscus L.) elucidated. Tetrahedron Letters, vol. 39, no. 17, p. 2645-2648. [CrossRef]

VAN DER DOELEN, G.A.; VAN DEN BERG, K.J. and BOON, J.J. (1998a). Comparative chromatographic and mass-spectrometric studies of triterpenoids varnishes: Fresh materials and aged simples from paintings. Studies in Conservation, vol. 43, no. 4, p. 249-264.

VAN DER DOELEN, G.A.; VAN DEN BERG, K.J.; BOON, J.J.; SHIBAYAMA, N.; DE LA RIE, E.R. and GENUIT, W.J.L. (1998b). Analysis of fresh triterpenoid resins and aged triterpenoid varnishes by high-performance liquid chromatography-atmospheric pressure chemical ionisation (tandem) mass spectrometry. Journal of Chromatography A, vol. 809, no. 1-2, p. 21-37. [CrossRef]

VAN DER DOELEN, G.A. and BOON, J.J. (2000). Artificial ageing of varnish triterpenoids in solution. Journal of Photochemistry and Photobiology A: Chemistry, vol. 134, no. 1-2, p. 45-57. [CrossRef] 


\section{How to cite this article:}

ROMERO-NOGUERA, J.; LÓPEZ-MIRAS, M.M.; MARTÍN-SÁNCHEZ, I.; RAMOS-LÓPEZ, J.M. and BOLÍVARGALIANO, F. (2010). An approach to the study of the fungal deterioration of a classical art material: Mastic varnish. Electronic Journal of Biotechnology, vol. 13, no. 6. http://dx.doi.org/10.2225/vol13-issue6-fulltext-11 